\title{
Development of Oral Tablet Formulation Containing Erlotinib: Randomly Methylated- $\beta$-cyclodextrin Inclusion Complex Using Direct Compression Method
}

\author{
Doğrudan Basım Yöntemi Kullanılarak Randomize Metillenmiş- \\ $\beta$-siklodekstrin İnklüzyon Kompleksi İçeren Erlotinib Oral Tablet \\ Formülasyonu Geliştirilmesi
}

\author{
(1) Nazlı ERDOĞAR* \\ Hacettepe University Faculty of Pharmacy, Department of Pharmaceutical Technology, Ankara, Turkey
}

\begin{abstract}
Objectives: Erlotinib (ERL) is a tyrosine kinase inhibitor that has been used in the treatment of metastatic non-small cell lung cancer (NSCLC). However, its low aqueous solubility limits its absorption and oral bioavailability. To overcome these pharmacokinetic drawbacks, complexation of ERL can be applied. The aim of this study was to develop and characterize an oral tablet formulation containing ERL: Randomly methylated- $\beta$ cyclodextrin (RAMEB-CD) inclusion complex to enhance solubility and oral bioavailability of ERL.

Materials and Methods: An inclusion complex was prepared with RAMEB-CD using co-lyophilization technique. Structural characterization was performed using X-ray diffractometry and fourier-transform infrared spectroscopy. Tablet formulation of ERL: RAMEB-CD inclusion complex were prepared using direct compression technique. Tablet characteristics like hardness, diameter, thickness, friability, weight variability, disintegration and dissolution were evaluated. Flow properties of the powder were also determined.

Results: Characterization studies suggested that stable complexes between ERL and RAMEB-CD were obtained with co-lyophilization method. Tablet formulation using inclusion complex of ERL and RAMEB-CD with drug dose equivalent to $25 \mathrm{mg}$ was successfully prepared using direct compression technique. Physical properties of the powder mixture were studied - angle of repose $\left({ }^{\circ}\right): 34.27 \pm 1.78$; flow time: $2.2 \pm 0.4$; HR: $1.05 \pm 0.02$; compressibility index: $14.27 \pm 1.55$. Moisture content (\%) was found to be $0.27 \pm 0.05$. The thickness, diameter and hardness values were $3.92 \pm 0.05$ $\mathrm{mm}, 11.3 \pm 0.06 \mathrm{~mm}$ and $81.38 \pm 2.27 \mathrm{~N}$, respectively. In uniformity of weight test, the average weight was $404.57 \pm 1.6 \mathrm{mg}$, with less than $5 \%$ deviation in 20 randomly selected tablets. Friability value was $0.27 \%$ and the disintegration time was found to be less than 15 min. Importantly, dissolution study showed that solubility of ERL was increased by complexation with RAMEB-CD. After 60 minutes, $99 \%$ of drug was released from the tablet formulation.
\end{abstract}

Conclusion: These results demonstrate that a new tablet formulation of ERL: RAMEB-CD inclusion complex could be an alternative approach to achieve increased dissolution and oral bioavailability of ERL for NSCLC treatment.

Key words: Erlotinib, inclusion complex, direct compression, dissolution

Öz

Amaç: Erlotinib (ERL) metastatik küçük hücreli akciğer kanserinde (NSCLC) kullanılan tirozin kinaz inhibitörüdür. Bununla birlikte, düşük suda çözünürlüğü absorpsiyonunu ve oral biyoyararlanımını sınırlamaktadır. Bu sakıncaların üstesinden gelmek için kompleksleșme yöntemi kullanılmaktadır. Çalıșmanın amacı ERL'nin çözünürlüğünü ve oral biyoyararlanımını artırmak için ERL: Randomize metillenmiş $\beta$-siklodekstrin (RAMEB-CD) inklüzyon kompleksi içeren oral tablet formülasyonu geliştirilmesi ve bu formülasyonun karakterize edilmesidir.

Gereç ve Yöntemler: RAMEB-CD siklodekstrin içeren inklüzyon kompleksi ko-liyofilizasyon yöntemi ile hazırlanmıștır. X-ray difraktometresi ve fourier-transform infrared spektroskopisi kullanılarak fizikokimyasal karakterizasyon yapılmıștır. Direkt basım yöntemi ile ERL: RAMEB- 
CD siklodekstrin inklüzyon kompleksi içeren tablet formülasyonu hazırlanmıştır. Sertlik, çap, kalınlık, kırılganlık, ağırlık değişkenliği, dağılma ve dissolüsyon gibi tablet özellikleri belirlenmiștir. Tozun akış özellikleri de tayin edilmiștir.

Bulgular: Karakterizasyon çalıșmaları ko-liyofilizasyon tekniği ile ERL ve RAMEB-CD arasında stabil kompleks elde edildiğini göstermiștir. Buna göre, direkt basım yöntemi ile 25 mg ilaç dozuna eşdeğer olacak şekilde ERL ve RAMEB-CD inklüzyon kompleksi kullanılarak tablet formülasyonu

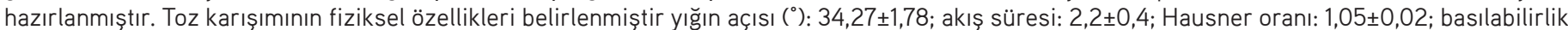

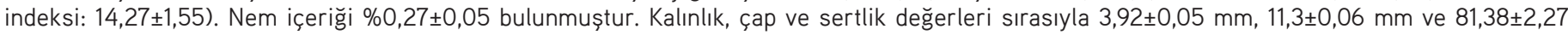
N olarak bulunmuştur. Ağırlık sapması testinde; ortalama tablet ağırlığı 404,57士1,6 mg olup rastgele seçilen 20 tablet için sapma \%5'ten küçüktür. Kırılganlık değeri \%0,27'dir. Dağılma zamanı 15 dakikadan az bulunmuștur. Dissolüsyon çalıșması RAMEB-CD ile kompleksleșme ile ERL'nin suda çözünürlüğünün önemli ölçüde arttığını göstermiştir. Altmış dakika sonunda ilacın \%99'u salınmıştır.

Sonuç: Elde edilen veriler ile ERL: RAMEB-CD inklüzyon kompleksi içeren yeni tablet formülasyonunun daha iyi çözünme ve oral biyoyararlanım elde etmek için NSCLC tedavisinde alternatif bir yaklaşım olabileceği sonucuna varılmıştır.

Anahtar kelimeler: Erlotinib, inklüzyon kompleksi, direkt basım, dissolüsyon

\section{INTRODUCTION}

Erlotinib (ERL) is a selective tyrosine kinase inhibitor which targets epidermal growth factor receptor (EGFR). ERL shows anticancer activity in EGFR-overexpressing tumors such as non-small cell lung cancer and pancreatic cancer.' ERL is commercially manufactured and available as a film-coated tablet $\left(\operatorname{Tarceva}^{\circledR}\right.$ ), approved by the European Medicines Agency and Food and Drug Administration (FDA). However, several properties of ERL have created challenges to its clinical use. ERL is a weak base with low aqueous solubility $(0.4 \mathrm{mg} / \mathrm{mL}$ at $\mathrm{pH}$ 2). Its low dissolution rate results in limited absorption and low bioavailability. When administered orally, ERL reaches its peak plasma concentration after approximately $4 \mathrm{~h}$, with bioavailability of $60 \%$. A plasma concentration of $44 \%$ is adequate for antitumor activity. ${ }^{2}$ Moreover, ERL can cause a wide range of adverse effect including diarrhea, rash, renal failure, thrombocytopenia, and neutropenia., ${ }^{3.4}$ Hence, novel formulations of ERL are needed to enhance its efficacy and safety. Different approaches reported to increase ERL solubility include solid dispersion, polymorphism, size reduction, and complexation. ${ }^{5,6}$ Also, a self-emulsifying formulation, ${ }^{7}$ a reverse micelle-loaded lipid nanocarrier formulation, ${ }^{8}$ and a sulfobutylether- $\beta$-cyclodextrin (CD) complex formation ${ }^{9}$ have been utilized to improve ERL bioavailability.

Recently, CD complexation has been employed to increase the solubility and bioavailability of hydrophobic drugs. CDs are cyclic oligosaccharides comprised of 6 or more glucopyranose units bound via $\alpha-(1,4)$ bonds. Natural CDs include $\alpha-, \beta$ - and $\gamma$-CDs with have 6,7 , and 8 glucose units, respectively..$^{\circ} \mathrm{CD}$ s contain a hydrophilic outer surface that results in their high aqueous solubility and a lipophilic cavity capable of accommodating several molecules to form inclusion complexes. Its structure impacts the physicochemical properties of encapsulated drugs by increasing their solubility, dissolution, and bioavailability.11-13

However, utilization of natural CDs as drug carriers has been limited due to their low solubility. Different chemical modifications of $C D$ have resulted in various $C D$ derivatives with enhanced aqueous solubility. ${ }^{9.14-16}$ Among the modified $C D$ s, randomly methylated $B-C D$ (RAMEB-CD) complexation with ERL has not been studied.

The purpose of this work was to develop and characterize a new tablet formulation containing the ERL: RAMEB-CD inclusion complex to increase dissolution and oral bioavailability of ERL. Additionally, flow properties and quality control parameters of the formulation were evaluated.

\section{MATERIALS AND METHODS}

\section{Materials}

ERL hydrochloride (molecular weight: $429.9 \mathrm{~g} / \mathrm{mol}$, Hetero Labs, Telangana, India) was a kind gift from Nobel Ilaç. RAMEB$C D$ was a kind gift from cyclolab (Budapest, Hungary). Acetone was purchased from Sigma-Aldrich (St. Louis, USA). Tween 80 was obtained from Merck-Schuchardt (Hohenbrunn, Germany). All other chemicals were of reagent grade and solvents were of high performance liquid chromatography (HPLC) grade. Lactose monohydrate and Avicel pH 102 was purchased from Sigma-Aldrich. Magnesium stearate was provided by Nitika Pharmaceuticals (Maharashtra, India). Sodium starch glycolate was purchased from Avebe (Foxhol, Netherlands).

\section{Preparation of ERL: RAMEB-CD inclusion complex}

ERL: RAMEB-CD inclusion complex was prepared by a lyophilization technique that could be was demonstrated in another study (data not shown). Briefly, ERL $(27.8 \mathrm{mg}, 21 \mathrm{mM})$ was dissolved in acetone $(3 \mathrm{~mL})$ and then slowly added to RAMEB-CD aqueous solution ( $82.1 \mathrm{mg}$ in $3 \mathrm{~mL}$ or $21 \mathrm{mM}$ ) to achieve a molar ratio of 1:1. The suspension was magnetically stirred at room temperature for $24 \mathrm{~h}$. The organic solvent was evaporated using a rotary evaporator (IKA RV 10 basic, Germany). The obtained solution was frozen at $-20^{\circ} \mathrm{C}$ and was lyophilized at $-80^{\circ} \mathrm{C}$ under $0.1 \mathrm{mbar}$ for $24 \mathrm{~h}$, resulting in a white fluffy powder (Labconco Freezone 4.5 Plus, USA).

\section{Characterization of ERL: RAMEB-CD inclusion complex}

\section{Fourier-transform infrared (FT-IR) spectroscopy}

FT-IR spectra of ERL, RAMEB-CD, physical mixture (PM), and ERL: RAMEB-CD inclusion complex were obtained using Perkin Elmer BX Spectrum (USA) at the range of $4000-500 \mathrm{~cm}^{-1}$ at ambient temperature.

\section{$X$-ray diffractometry ( $X R D$ )}

The XRD patterns of ERL, RAMEB-CD, PM, and ERL: RAMEB$C D$ inclusion complex were obtained using a Multipurpose X-ray Diffraction Multipurpose Diffractometer (X'Pert Pro MPD, Malvern PANalytical, UK) with Cu Ka radiation powered at 
voltage $45 \mathrm{kV}$ and current $40 \mathrm{~mA}$. The diffraction angle $(2 \theta)$ was between $3^{\circ}-40^{\circ}$ and the scanning rate was $2^{\circ} / \mathrm{min}$.

Preparation of tablet formulation containing ERL: RAMEB-CD inclusion complex

Tablet formulations containing lyophilized ERL: RAMEB-CD inclusion complex (equivalent to $25 \mathrm{mg} E R L$ ) was prepared by direct compression method using excipients shown in Table 1. Tablet formulations were manufactured based on the commercial drug $\operatorname{Tarceva}^{\circledR}{ }^{\circledR 17}$ It contains $31 \%$ lactose monohydrate and 33\% Avicel pH 102 as fillers, 8\% sodium starch glycolate as a super disintegrant, and $1 \%$ magnesium stearate as a lubricant. Using a roller mixer, ERL: RAMEB-CD inclusion complex was blended with lactose monohydrate and Avicel pH 102 for 5 min. Sodium starch glycolate was added into the mixture in small increments. Finally, the powder mixture was mixed with magnesium stearate. Tablet weight was adjusted to $400 \mathrm{mg}$ and tablets were compressed using Erweka AR 400 (Heusenstamm, Germany) to manufacture oral tablet formulations containing ERL: RAMEB-CD complex.

\section{Powder flow properties}

The angle of repose $\left({ }^{\circ}\right)$

The angle of repose was determined using the fixed height funnel standing technique. A standard funnel was physically secured and powder was allowed to flow through the orifice of the funnel cone. The radius ( $r$ ) of the base and height of powder mass ( $h$ ) was measured, and was calculated using this formula:

$$
\tan (\alpha)=\frac{\text { height }}{0.5 \text { xbase }}
$$

The flow time was evaluated with a standard funnel. The results were given as mean \pm standard deviation (SD).

Hausner ratio (HR) and compressibility index:

The HR and compressibility index are two parameters that can be calculated to predict the characteristics of powder flow. The two indices are calculated as follows:

$$
\begin{aligned}
\text { Hausner ratio } & =\frac{V o}{V f} \\
\text { Compressibility index } & =100 x \frac{V o-V f}{V o}
\end{aligned}
$$

where $\mathrm{V}_{0}$ : Bulk volume; $\mathrm{V}_{\mathrm{f}}$ : Tapped volume of powder.

Table 1. Components of tablet formulation containing ERL: RAMEB-CD inclusion complex

\begin{tabular}{lll} 
Components & Amount (mg) & Percent (\%) \\
\hline ERL-RAMEB complex & 109 & 27 \\
\hline Lactose monohydrate & 123 & 31 \\
\hline Avicel pH 102 & 132 & 33 \\
\hline Sodium starch glycolate & 32 & 8 \\
\hline Magnesium stearate & 4 & 1 \\
\hline
\end{tabular}

ERL: Erlotinib, RAMEB-CD: Randomly methylated- $\beta$-cyclodextrin

\section{Bulk/tapped volume and density}

The bulk $\left(\mathrm{V}_{0}\right)$ and apparent volumes $\left(\mathrm{V}_{10}, \mathrm{~V}_{500}\right.$, and $\left.\mathrm{V}_{1250}\right)$ of powder mixture $(50 \mathrm{~g}$ ) were measured in a $100 \mathrm{~mL}$ cylindrical vessel. Because the difference between $V_{500}$ and $V_{1250}$ was less than $2 \mathrm{~mL}, \mathrm{~V}_{1250}$ was considered as the tapped volume. Bulk and tapped densities were calculated as below:

$$
\begin{aligned}
\text { Bulk density } & =\frac{m}{V o} \\
\text { Tapped density } & =\frac{m}{\mathrm{~V} 1250}
\end{aligned}
$$

$\mathrm{m}$ : Sample weight $(\mathrm{g}), \mathrm{V}_{0}$ : The bulk volume $(\mathrm{mL}), \mathrm{V}_{1250}$ : The tapped volume $(\mathrm{mL})$.

\section{Moisture content (\%)}

$3 \mathrm{~g}$ of powder were heated at $102^{\circ} \mathrm{C}$ (Ohaus MB45 Moisture Analyzer, Parsippany, USA) until the weight remained constant.

Quality control tests for tablets containing ERL: RAMEB-CD inclusion complex

Hardness, thickness and diameter

Hardness $(n=10)$, diameter $(n=20)$, and thickness $(n=20)$ of tablets were measured using a Pharma test PTB 311E (Hainburg, Germany).

\section{Friability}

Tablets $(n=20)$ were weighed, then placed in a friabilator (Pharma test PTF 10E, Hainburg, Germany). After rotating at 100 cycles, the final weight of tablets was checked. Percent weight loss was calculated.

\section{Uniformity of weight}

Tablets ( $n=20)$ were weighed individually. The average mass and SD were calculated.

\section{Disintegration test}

The disintegration test of tablets was performed using Pharma test PTZ-S (Hainburg, Germany) in $1 \mathrm{~L}$ of purified water at $37^{\circ} \mathrm{C}$. Tablets $(n=6)$ were placed in cylindrical tubes of the system and, then the device started to move in a periodic upwarddownward manner automatically. The time for each tablet to disintegrate was recorded.

\section{Dissolution test}

The dissolution experiment was undertaken using the FDA dissolution methods database..$^{18}$ It was performed using a paddle (USP Apparatus 2) in 0.02\% Tween 80 in $0.01 \mathrm{~N} \mathrm{HCl}(1000 \mathrm{~mL})$ at 75 rpm. Tablets containing ERL: RAMEB-CD inclusion complex and ERL tablets (containing $25 \mathrm{mg}$ ERL) were added to 1000 $\mathrm{mL}$ medium (Sotax Dissolution Testing Device, Switzerland). At various time points $(5,1015,20,30,45,60 \mathrm{~min}), 2 \mathrm{~mL}$ of aliquot was withdrawn and replaced with the same volume of fresh medium. All samples were filtered through a $0.45 \mu \mathrm{m}$ filter. The filtrate was analyzed by an analytically validated HPLC method $\left(r^{2}\right.$ : 0.9992). These methods consist of a Kromasil ${ }^{\circledR}$ reversedphase C18 (250x4.6 mm) column andammonium acetate buffer $(\mathrm{pH} 4)$ : Acetonitrile $(65: 35 \mathrm{v} / \mathrm{v})$ as the mobile phase, with

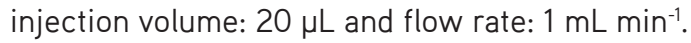




\section{RESULTS AND DISCUSSION}

\section{Characterization of ERL: RAMEB-CD inclusion complex}

ERL: RAMEB-CD inclusion complex was prepared with lyophilization technique and resulted in improved ERL solubility. Complexation between drugs and $C D$ may be mediated by van der Waals and non-bonding forces. The ERL: CD ratio (1:1) used resulted in adequation interactions between the hydrophobic region of the drug and $C D$ and allowed successful complexation. Moreover, a stronger interaction between RAMEB-CD and ERL could be due to the lipophilic methyl groups on the RAMEB$C D$ ring which confers higher solubility and solubilization properties. 19,20

Figure 1 shows the FT-IR spectra of ERL, RAMEB-CD, PM and ERL: RAMEB-CD inclusion complex. ERL spectrum displayed strong absorption bands at $3277 \mathrm{~cm}^{-1}$ (for $\mathrm{CH}_{3}, \mathrm{C}-\mathrm{H}$ stretching vibrations), $1634 \mathrm{~cm}^{-1}$ (for $\mathrm{NH}$, secondary amine bending vibrations), $3277 \mathrm{~cm}^{-1}$ (for $\equiv \mathrm{C}-\mathrm{H}$ stretching vibrations), 1238 $\mathrm{cm}^{-1}, 1069 \mathrm{~cm}^{-1}$ (for phenyl ether group) and $1021 \mathrm{~cm}^{-1}$ (for aliphatic ether group), which is in agreement with findings reported by Parthasaradhi et al. ${ }^{21}$ The spectrum of RAMEB-CD was characterized by intense bands at $3300-3500 \mathrm{~cm}^{-1}(\mathrm{O}-\mathrm{H}$ stretching vibration) and $2800-3000 \mathrm{~cm}^{-1}$ (for $-\mathrm{CH}$ and $-\mathrm{CH}_{2}-$ groups).22 FT-IR spectrum of PM showed bands that appear as the superposition of the spectra of both ERL and RAMEB-CD, with no shift of the absorption band at $3277 \mathrm{~cm}^{-1}$ and $1634 \mathrm{~cm}^{-1}$. However, significant changes were observed in the peak widths at the center-frequencies (1634 $\mathrm{cm}^{-1}$ and $3277 \mathrm{~cm}^{-1}$ ) of the characteristic absorption peaks of ERL. This peak broadening and disappearance of the ERL characteristic peak indicated ERL-RAMEB-CD interaction and validates the formation of the inclusion complex of ERL: RAMEB-CD (Figure 1).

The XRD patterns of ERL, RAMEB-CD, PM and ERL: RAMEB$C D$ inclusion complex are shown in Figure 2. The XRD pattern of ERL showed the presence of strong, sharp peaks at 5.66, $9.74,11.32,18.95,22.78,23.6,24.24,30.07$ on $2 \theta$, confirming the crystalline nature of ERL. The XRD pattern of RAMEB$C D$ displayed two broad peaks and multiple undefined, diffuse peaks with low intensities, indicating the amorphous structure of CD. ${ }^{23}$ The PM showed very few of the crystalline ERL peaks, but with decreased intensities and no sharp peaks. In contrast,

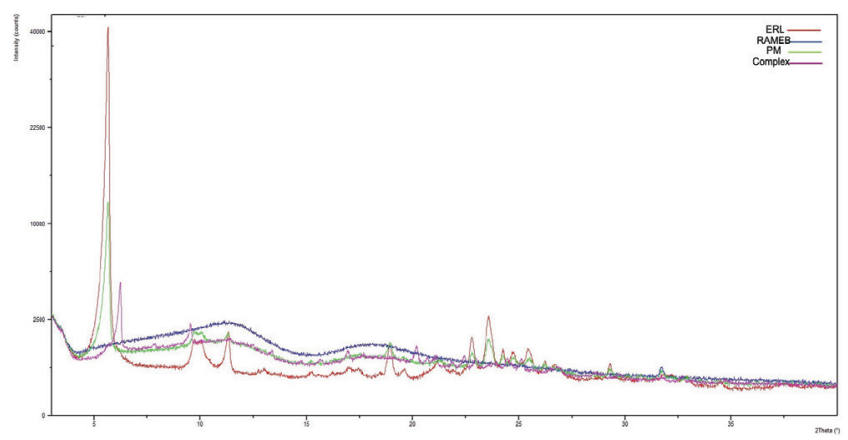

Figure 2. X-ray diffractometry patterns of ERL, RAMEB-CD, PM, and ERL: RAMEB-CD inclusion complex

ERL: Erlotinib, RAMEB-CD: Randomly methylated- $\beta$-cyclodextrin, PM: Physical mixture

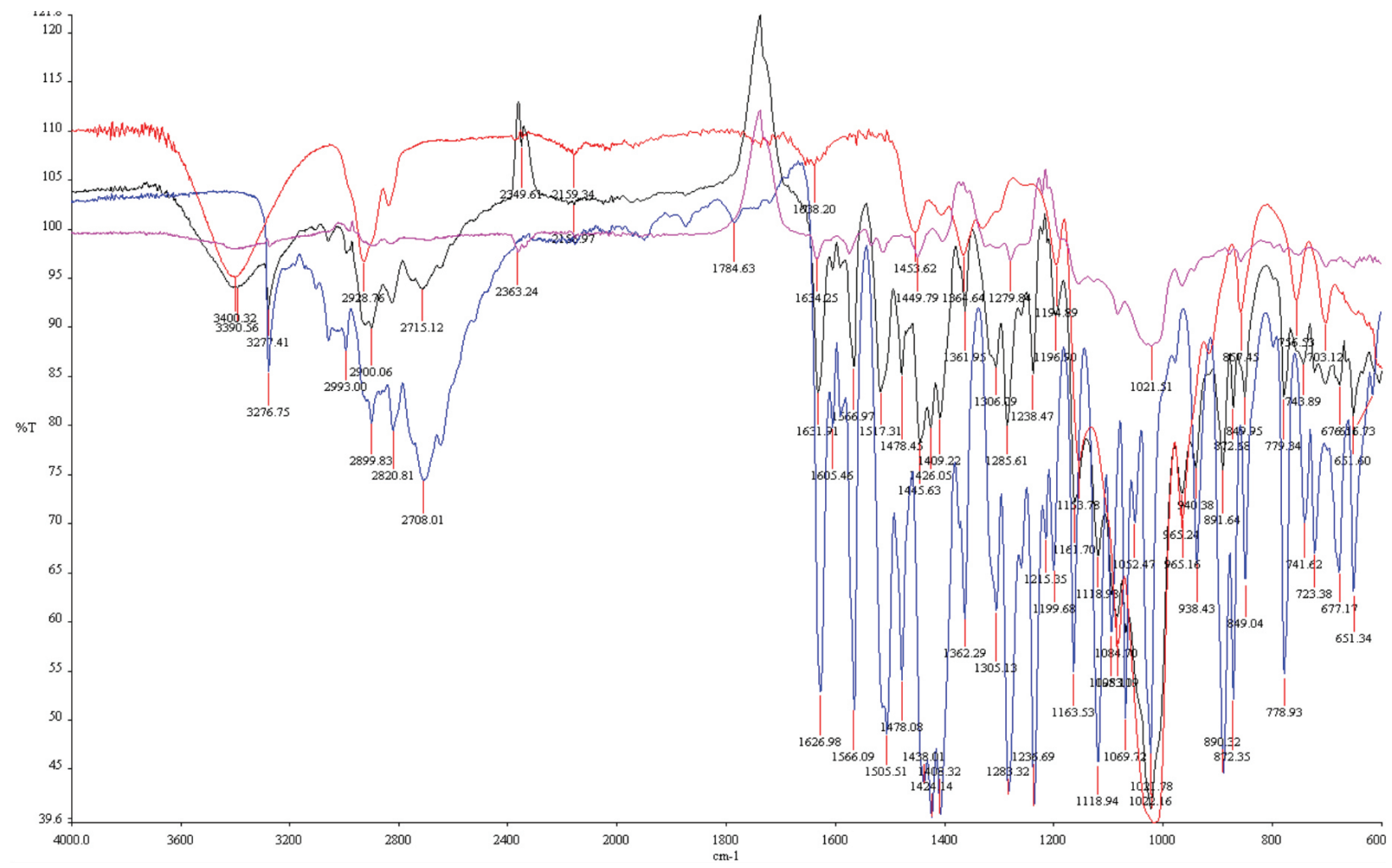

Figure 1. FT-IR spectra of ERL, RAMEB-CD, PM, and ERL: RAMEB-CD inclusion complex

FT-IR: Fourier-transform infrared, ERL: Erlotinib, RAMEB-CD: Randomly methylated- $\beta$-cyclodextrin, PM: Physical mixture 
compared to the XRD patterns of ERL and RAMEB-CD, the inclusion complex presented an amorphous state, due to both the CD structure and post-lyophilization effects. ${ }^{9}$ The inclusion complex diffractometric profile had less intense RAMEB$C D$ peaks and the absence of the ERL sharp characteristic peaks, thus suggesting that ERL is in an amorphous state. This reduction in ERL crystallinity provides further evidence to the formation of the ERL: RAMEB-CD inclusion complex in solidstate, in agreement with FT-IR results. ${ }^{24}$

\section{The flow properties of powder mixture in tablet formulation}

The powder mixture, consisting of drug-CD inclusion complex and excipients, was prepared and its flow properties, such as the angle of repose, compressibility index, HR and moisture content, were measured. The angle of repose is a predictor of flow characteristics of all powder mixtures. In ERL: RAMEB$C D$ formulation in this study, the angle of repose measured was $34.27 \pm 1.78$, indicating good flow property according to the United States Pharmacopeia (USP) specifications. HR and compressibility index were $1.05 \pm 0.02$ and 14.27 \pm 1.55 , respectively, which further support good flow properties according to USP $30 .{ }^{25}$ The moisture content is another important parameter contributing to powder flow. In our study, the moisture content (\%) was found $0.27 \pm 0.05 \%$, which can enable binding of drugs with excipients during the manufacturing process. These data showed that the prepared powder displayed good flow properties and was favorable for direct compression technique.

\section{Quality-control tests for tablets containing ERL: RAMEB CD inclusion complex}

In this study, all of the tablets were manufactured with uniform appearance and appropriate physical characteristics. The thickness and diameter of tablets are between $3.92 \pm 0.05 \mathrm{~mm}$ and $11.3 \pm 0.06 \mathrm{~mm}$, respectively. The very low variabilities in thickness and diameter showed that the operation and weighing of the powder mixture are appropriate during the manufacturing process. The hardness value was $81.38 \pm 2.27 \mathrm{~N}$ for tablets containing ERL: RAMEB-CD inclusion complex, showing that tablets had suitable crushing strength to resist abrasion.

Friability is a significant parameter that points out the tablet's capability to resist abrasion along with packaging, transport, and handling; compendial specification not more than $1 \% .^{26}$ Friability value was $0.27 \%$ for tablet formulation containing ERL: RAMEB-CD inclusion complex (Table 2). This data correlates the pharmacopeia criteria and shows that tablets probably have adequately high mechanical stress during the process, handling and transportation. ${ }^{27}$

The uniformity of weight (or weight variation) of prepared tablets was evaluated by USP 30 . The average weight of prepared tablets was found $404.57 \pm 1.6 \mathrm{mg}$, with less than $5 \%$ deviation for 20 tablets, which meets the acceptability criteria of USP. ${ }^{28}$ These results suggested that the powder mixture retained homogeneity during the preparation and manufacturing process.
For all tablets, the first important step towards drug dissolution is the breakdown of the tablets into granules or primary powder particles in a process known as disintegration. The disintegration time of the tablet formulation containing ERL: RAMEB-CD inclusion complex was compatible to USP 30 standards which require that uncoated tablets have disintegration time standard values less than 15 minutes (Table 2).

Before performing the dissolution test, the HPLC method was validated. The linearity of the calibration curves was established over the concentration range of $1-200 \mu \mathrm{g} / \mathrm{mL}$ with a correlation coefficient value of $0.9992 \pm 0.01$, indicating acceptable linearity in this range. The values (mean \pm standard error; $n=3$ ) of the slope and intercept were 60.103 and 19.837, respectively. The limit of detection was $0.21 \mu \mathrm{g} / \mathrm{mL}$ and the limit of quantitation was $0.71 \mu \mathrm{g} / \mathrm{mL}$, both with acceptable accuracy and precision. To determine the accuracy of analytical method, six solutions with three different concentrations $(0.5,10$ and $50 \mathrm{mg} / \mathrm{mL})$ of the formulation were prepared and HPLC analysis was done. Mean recovery of ERL recovery and coefficient of variation (CV) were calculated as shown in Table 3 . The recovery value was determined as $101.82 \% \pm 3.7$ with $\mathrm{CV}$ below $2 \%$. The calculated CV was found suitable according to FDA, International Council for Harmonisation of Technical Requirements for Pharmaceuticals for Human Use, and USP's validation guidelines. To determine the precision of the analytical method, reproducibility and interday precision analysis were done. Data are shown in Table 4 and Table 5. CVs was found to be below $2 \%$ therefore, indicating that the precision and accuracy of the method were sufficient.

Figure 3 represents dissolution profiles of ERL tablet and ERL: RAMEB-CD tablet. The tablet containing the inclusion complex showed $70.43 \%$ dissolved drug at 10 minutes; an approximately 2.5 -fold increase in drug dissolution comparison to ERL alone $(30.2 \%)$. At one hour, the tablet containing the inclusion complex released $98.57 \%$ of the drug, while the ERL tablet dissolved $46.51 \%$, indicating an approximately two-fold increase in dissolution. This increase in dissolution may due to the solubilization effect of $C D$, the particle size reduction at the molecular level, and the formation of hydrogen bonds in the complex. ${ }^{29}$

\begin{tabular}{l}
$\begin{array}{l}\text { Table 2. Results from the quality control tests for tablets } \\
\text { containing ERL: RAMEB-CD inclusion complex }\end{array}$ \\
\begin{tabular}{ll} 
Parameter & Value (mean \pm SD) \\
\hline Thickness $(n=20)$ & $3.92 \pm 0.05 \mathrm{~mm}$ \\
\hline Diameter $(n=20)$ & $11.3 \pm 0.06 \mathrm{~mm}$ \\
\hline Hardness $(n=10)$ & $81.38 \pm 2.27 \mathrm{~N}$ \\
\hline Friability $(n=20)$ & $0.27 \%$ \\
\hline Uniformity of weight $(n=20)$ & $404.57 \pm 1.6 \mathrm{mg}$ \\
\hline Disintegration time $(n=6)$ & $5 \mathrm{~min}$
\end{tabular} \\
\hline
\end{tabular}

ERL: Erlotinib, RAMEB-CD: Randomly methylated- $\beta$-cyclodextrin, SD: Standard deviation 
Table 3. Coefficient of variation and \% recovery of erlotinib

\begin{tabular}{llll} 
Sample number & $10 \mu \mathrm{g} / \mathrm{mL} \%$ recovery & $50 \mu \mathrm{g} / \mathrm{mL}$ recovery & $150 \mu \mathrm{g} / \mathrm{mL}$ recovery \\
\hline $\mathbf{1}$ & 9.87 & 50.59 & 150.07 \\
\hline $\mathbf{2}$ & 10.19 & 51.85 & 154.55 \\
\hline $\mathbf{4}$ & 9.75 & 51.95 & 156.66 \\
\hline $\mathbf{5}$ & 9.8 & 50.28 & 154.92 \\
\hline 6 & 9.82 & 51.21 & 155.7 \\
\hline $\mathrm{X}$ & 9.84 & 49.54 & 150.46 \\
\hline SD & 9.88 & 50.9 & 153.73 \\
\hline CV & 0.18 & 0.94 & 2.78 \\
\hline
\end{tabular}

SD: Standard deviation, CV: Coefficient of variation

Table 4. Repeatability results of erlotinib $(n=6)$

\begin{tabular}{|c|c|c|c|c|}
\hline Sample & Concentration $(\mu \mathrm{g} / \mathrm{mL})$ & $x$ & SD & CV \\
\hline 1 & 50.28 & \multirow{4}{*}{50.82} & \multirow{4}{*}{0.89} & \multirow{4}{*}{1.76} \\
\hline 2 & 50.43 & & & \\
\hline 3 & 50.26 & & & \\
\hline 4 & 50.37 & & & \\
\hline
\end{tabular}

SD: Standard deviation, CV: Coefficient of variation

Table 5. Inter-day precision results of erlotinib $(n=6)$

\begin{tabular}{lllll} 
Sample & Concentration $(\mu \mathrm{g} / \mathrm{mL})$ & $X$ & SD & CV \\
\cline { 1 - 2 } $\mathbf{1}$ & 50.59 & & & \\
\cline { 1 - 3 } & 51.92 & 51.47 & 0.76 & 1.49 \\
\hline
\end{tabular}

SD: Standard deviation, CV: Coefficient of variation

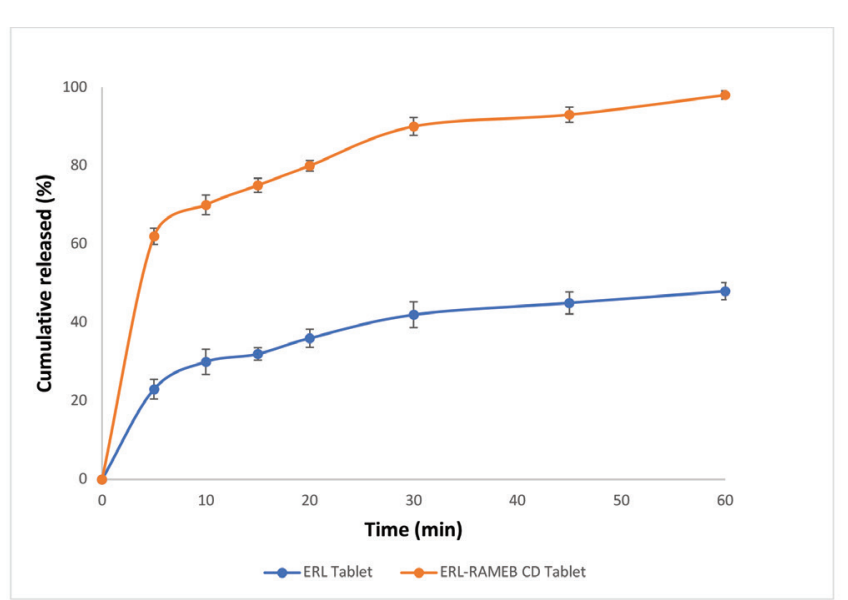

Figure 3. Dissolution profiles of erlotinib tablet and ERL: RAMEB-CD tablet in $0.02 \%$ Tween 80 in $0.01 \mathrm{~N} \mathrm{HCl}$ under sink conditions ( $n=6$, mean \pm SD) ERL: Erlotinib, RAMEB-CD: Randomly methylated- $\beta$-cyclodextrin, SD: Standard deviation
The similarity factor $\left(f_{2}\right)$ was used to compare the dissolution profiles. If the $f_{2}$ value is $50-100$, the curves can be considered as similar. ${ }^{30} \mathrm{f}_{2}$ obtained between the two dissolution curves of ERL and inclusion complex was 11, suggesting that release behaviors for inclusion complex differed from that for ERL. These findings suggest that RAMEB-CD was able to form a water-soluble inclusion complex with ERL and improved its dissolution rate. ${ }^{31,32}$ This improvement in the solubility properties of ERL could result in enhanced bioavailability and could possibly minimize the dose-limited side effects. Therefore, complexation with RAMEB-CD possesses great potential in improving the therapeutic and safety profile of ERL.

\section{CONCLUSION}

In this study, ERL: RAMEB-CD inclusion complex was successfully developed and evaluated. The inclusion complex was characterized by XRD and FT-IR studies and confirmed the formation of the inclusion complex. A novel tablet formulation 
of ERL: RAMEB-CD inclusion complex was prepared by a direct compression method. In vitro dissolution studies demonstrated the increase in aqueous solubility and dissolution rate of the complex. In summary, this study applies an effective method of $C D$ complexation to overcome limited drug solubility and allow the preparation of an efficient oral dosage form of ERL to increase its efficacy and reduce its adverse effects.

Conflict of interest: No conflict of interest was declared by the author. The author are solely responsible for the content and writing of this paper.

\section{REFERENCES}

1. Soulieres D, Senzer NN, Vokes EE, Hidalgo M, Agarwala SS, Siu LL. Multicenter phase II study of erlotinib, an oral epidermal growth factor receptor tyrosine kinase inhibitor, in patients with recurrent or metastatic squamous cell cancer of the head and neck. J Clin Oncol. 2004:22:77-85.

2. Thomas SM, Grandis JR. Pharmacokinetic and pharmacodynamic properties of EGFR inhibitors under clinical investigation. Cancer Treat Rev. 2004;30:255-268.

3. Fan L, Hu L, Yang B, Fang X, Gao Z, Li W, Sun Y, Shen Y, Wu X, Shu Y, Gu $Y$, Wu X, Xu Q. Erlotinib promotes endoplasmic reticulum stressmediated injury in the intestinal epithelium. Toxicol Appl Pharmacol. 2014;278:45-52.

4. Herchenhorn D, Dias FL, Viegas CM, Federico MH, Araujo CM, Small I, Bezerra M, Fontao K, Knust RE, Ferreira CG, Martins RG. Phase I/II study of erlotinib combined with cisplatin and radiotherapy in patients with locally advanced squamous cell carcinoma of the head and neck. Int J Radiat Oncol Biol Phys. 2010;78:696-702.

5. Chaudhari SP, Dugar RP. Application of surfactants in solid dispersion technology for improving the solubility of poorly water-soluble drugs. J Drug Deliv Sci Tech. 2017;41:68-77.

6. Vimalson DC, Parimalakrishnan S, Jeganathan NS, Anbazhagan S. Techniques to enhance solubility of hydrophobic drugs: an overview. Asian J Pharm. 2016;10:S67-S75.

7. Truong DH, Tran TH, Ramasamy T, Choi JY, Lee HH, Moon C, Choi HG, Yong CS, Kim JO. Development of Solid Self-Emulsifying Formulation for Improving the Oral Bioavailability of Erlotinib. AAPS PharmSciTech. 2016;17:466-473.

8. Vrignaud S, Hureaux J, Wack S, Benoit JP, Saulnier P. Design, optimization and in vitro evaluation of reverse micelle-loaded lipid nanocarriers containing erlotinib hydrochloride. Int J Pharm. 2012;436:194-200.

9. Devasari N, Dora CP, Singh C, Paidi SR, Kumar V, Sobhia ME, Suresh S. Inclusion complex of erlotinib with sulfobutyl ether-beta-cyclodextrin: Preparation, characterization, in silico, in vitro and in vivo evaluation. Carbohydr Polym. 2015;134:547-556.

10. Kwon S, Lee W, Shin HJ, Yoon SI, Kim YT, Kim YJ, Lee K, Lee S. Characterization of cyclodextrin complexes of camostat mesylate by ESI mass spectrometry and NMR spectroscopy. J Mol Struct. 2009;938:192197.

11. Karathanos VT, Mourtzinos I, Yannakopoulou K, Andrikopoulos NK. Study of the solubility, antioxidant activity and structure of inclusion complex of vanillin with beta-cyclodextrin. Food Chem. 2007;101:652-658.

12. Lyra MAM, Soares-Sobrinho JL, Figueiredo RCBQ, Sandes JM, Lima AAN, Tenorio RP, Fontes DAF, Santos FLA, Rolim LA, Rolim-Neto PJ.
Study of benznidazole-cyclodextrin inclusion complexes, cytotoxicity and trypanocidal activity. J Incl Phenom Macrocycl Chem. 2012;73:397404.

13. Wang DW, Ouyang CB, Liu Q, Yuan HL, Liu XH. Inclusion of quinestrol and 2,6-di-O-methyl-beta-cyclodextrin: Preparation, characterization, and inclusion mode. Carbohydr Polym. 2013;93:753-760.

14. Vaidya B, Parvathaneni V, Kulkarni NS, Shukla SK, Damon JK, Sarode A, Kanabar D, Garcia JV, Mitragotri S, Muth A, Gupta V. Cyclodextrin modified erlotinib loaded PLGA nanoparticles for improved therapeutic efficacy against non-small cell lung cancer. Int J Biol Macromol. 2019;122:338-347.

15. Gontijo S, Guimarães P, Viana C, Denadai A, Gomes A, Campos P, Andrade $S$, Sinisterra R, Cortés M. Erlotinib/hydroxypropyl- $\beta$-cyclodextrin inclusion complex: characterization and in vitro and in vivo evaluation. $J$ Incl Phenom Macrocycl Chem. 2015;83:267-279.

16. Polat HK, Bozdag Pehlivan S, Ozkul C, Calamak S, Ozturk N, Aytekin E, Firat A, Ulubayram K, Kocabeyoglu S, Irkec M, Calis S. Development of besifloxacin $\mathrm{HCl}$ loaded nanofibrous ocular inserts for the treatment of bacterial keratitis: In vitro, ex vivo and in vivo evaluation. Int J Pharm. 2020;585:119552.

17. ANNEX I Summary of Product Characteristics. Available from: https:// www.ema.europa.eu/en/documents/product-information/tarceva-eparproduct-information_en.pdf

18. Dissolution Methods. Available from: https://www.accessdata.fda.gov/ scripts/cder/dissolution/dsp_SearchResults.cfm

19. Jansook P, Ogawa N, Loftsson T. Cyclodextrins: Structure, physicochemical properties and pharmaceutical applications. Int J Pharm. 2018;535:272-284.

20. Fenyvesi F, Nguyen TLP, Haimhoffer A, Rusznyak A, Vasvari G, Bacskay I, Vecsernyes M, Ignat SR, Dinescu S, Costache M, Ciceu A, Hermenean A, Varadi J. Cyclodextrin complexation improves the solubility and caco2 permeability of chrysin. Materials. 2020;13:3618.

21. Parthasaradhi B, Rathnakar K, Raji R, Muralidhara D, Srinivasa T. Erlotinib hydrochloride polymorph Form A substantially free of polymorph Form B. EP2218713A1, 2007. Available from: https://patents.google.com/ patent/EP2218713A1/en

22. Nicolescu C, Arama C, Monciu CM. Preparation and characterization of inclusion complexes between repaglinide and $\beta$-cyclodextrin, 2 -hydroxypropyl- $\beta$-cyclodextrin and randomly methylated $\beta$-cyclodextrin. Farmacia. 2010;58:78-88.

23. Sbarcea L, Udrescu L, Dragan L, Trandafirescu C, Szabadai Z, Bojita M. Fosinopril-cyclodextrin inclusion complexes: phase solubility and physicochemical analysis. Pharmazie. 2011;66:584-589.

24. Tănase I, Sbârcea L, Ledeți A, Vlase G, Barvinschi $P$, Văruţ $R$, Dragomirescu A, Axente C, Ledeți I. Physicochemical characterization and molecular modeling study of host-guest systems of aripiprazole and functionalized cyclodextrins. J Therm Anal Calorim. 2020;141:1027-1039.

25. USP 30-NF 25 Powder Flow. 2005:643. Available from: https://www. uspnf.com/?gclid=CjwKCAjw7rWKBhAtEiwAJ3CWLJzOpJM7-h9SjpcrN DZQnGNSDABpbbTXfIMyMcjKtACsWz56GuuOAxoCcOYQAvD_BwE

26. Second Interim Revision Announcement: 〈1216〉 Tablet Friability. 2016:32. Available from: https:/www.usp.org/sites/default/files/usp/ document/harmonization/gen-chapter/g06_pf_ira_32_2_2006.pdf

27. European Pharmacopoeia. Shutdown of European Pharmacopoeia. (8th ed). Strasbourg: European Pharmacopoeia; 2014. 
28. Uniformity of Dosage Units Content Uniformity USP 30-NF 25. 2005;905-910. Available from: https:/www.usp.org/sites/default/ files/usp/document/harmonization/gen-method/q0304_stage_6_ monograph_25_feb_2011.pdf

29. Jadhav P, Petkar B, Pore Y, Kulkarni A, Burade K. Physicochemical and molecular modeling studies of cefixime-L-arginine-cyclodextrin ternary inclusion compounds. Carbohydr Polym. 2013;98:1317-1325.

30. Dissolution Testing of Immediate Release SolidOral Dosage Forms; Guidance for Industry; U.S. Department of Health and Human Services,
Food and Drug Administration, Center for Drug Evaluation and Research (CDER), U.S. Government Printing Office: Washington, DC, 1997. Last Accessed Date: 29.09.2008. Available from: http://www.fda.gov/ cder/ guidance/1713bp1.pdf

31. Loftsson T, Hreinsdottir D, Masson M. Evaluation of cyclodextrin solubilization of drugs. Int J Pharm. 2005;302:18-28.

32. Loftsson T, Jarho P, Masson M, Järvinen T. Cyclodextrins in drug delivery. Expert Opin Drug Deliv. 2005;2:335-351. 